\title{
Nine Channel Temperature Data Logger in Measuring the Effectiveness of the Sterilization Process of Medical Instruments with Dry Sterilization
}

\author{
Nurul Al Istigho Farola, Her Gumiwang Ariswati, and Sumber \\ Departement of Electromedical Engineering Poltekkes Kemenkes, Surabaya
}

Corresponding author: Nurul A1 Istigho Farola (e-mail: p27838018001@ gmail.com).

ABSTRACT Measuring the temperature on the dry sterilizer is very necessary to prevent the spread of microorganisms. The temperature inside the dry sterilizer may have a different temperature from the temperature that has been set and is displayed on the display screen. If the temperature inside the dry sterilizer is not in accordance with what has been previously set, the sterilization process cannot achieve optimal results. The aim of this study is to record and monitor the suitability of the temperature distribution in the dry sterilization chamber with the temperature that has been set. The workings of the temperature data recording device or type $\mathrm{K}$ thermocouple temperature sensor is to detect the temperature. Furthermore, the results obtained enter the analog signal conditioning circuit which is then continued to the AT Mega 2560 which has been programmed and processed. Then the temperature will be displayed on the $4 \times 20$ character LCD. Temperature measurement data will be saved to SD card every 10 seconds in the form of TXT file. This research has attempted to record 2 sterilizers and compare them with the Madgetech OctTemp2000 data logger. Based on the measurement and comparison data, the average error was obtained at a temperature of $50^{\circ} \mathrm{C}$ with the smallest error value of $0.7 \%$ and the largest value of $3.9 \%$. At a temperature of $100^{\circ} \mathrm{C}$ the smallest error value is $1.6 \%$ and the largest is $10.5 \%$. Then at a temperature of $120^{\circ} \mathrm{C}$ the smallest error value is $0.0 \%$ and the largest is $8.5 \%$. This research can be used to help analyze the temperature distribution in a sterilizer chamber. However, there is still a fairly high error value at some basic points of measurement in this study.

INDEX TERMS Data Logger, Thermocouple, Sterilizer

\section{INTRODUCTION}

Measuring the temperature on the dry sterilizer is very important because it relates to patient safety. There is a possibility that the temperature inside the dry sterilizer does not match the temperature that has been set on the temperature display. If the temperature in the dry sterilizer does not match the standard-setting temperature, then the sterilization process is not perfect. When the temperature does not reach the setting, it causes microorganisms to remain on the sterilized object or medical instrument. However, whether the temperature exceeds the setting temperature, it can damage the material or medical instrument being sterilized. Sterilization is a process to kill living microorganisms by using heat. [1]. Dry heat sterilization is the most effective method for killing microorganisms in glassware and many surgical medical instruments. Dry heat sterilization uses a heater from a dry element that is electrified so that there is a hot temperature that fills the room, where the temperature has been set according to the needs of the sterilization process. A process in detecting and monitoring the results of information about temperature is called a data logger. Data Logger is an electronic device that records data 
from time to time, both integrated with sensors and instruments in it and external sensors and instruments. In short, a data logger is a tool for data logging. The data obtained from the temperature sensor is stored in a data logger, then the data is compared with the temperature on the display of the dry sterilizer.

This temperature data logger tool is used several times, in 2010 Micky Virgo conducted a focused study with a system from a data logger, this study used the LM35 temperature sensor only as a data source [1]. In 2015 Dwinta Mussetyarsih made a research data logger in this study using an LM35 temperature sensor with a temperature measurement range of $60^{\circ}-100^{\circ} \mathrm{C}$, temperature data was stored using an SD Card in the form of a CSV file[2]. Risky Bian Primaswara conducted research in 2016. In this study the author uses 2 thermocouple temperature sensor channels with a range of $50^{\circ}-170^{\circ} \mathrm{C}$, the temperature read was stored on the SD card and displayed on a PC[3]. Agus Dwi Korawan conducted a study in 2018. In this study, the authors used 16 NTC $7.5 \mathrm{~K}$ thermistor sensors with temperature data storage using an SD Card, and data processing using ATmega2560 [4]. In 2020 Rismawati and Muhammad Sadli conducted research on Temperature Sensor Data Logger using the Atmega16 Microcontroller [5], in this study, there were 4 channels using the LM35 sensor and data storage via a USB module with txt and xls file formats.

In previous studies, some still used LM35 and NTC $7.5 \mathrm{~K}$ Probe thermistors as temperature sensors, where they were based on specifications that can only detect up to $+/-100^{\circ} \mathrm{C}$ temperatures. some also still had a little channel. The purpose of the study was to record and monitor whether the distributed temperature in the sterilization chamber corresponds to the set temperature.

The purpose of this study is to record and monitor whether the distributed temperature inside the sterilization chamber matched the temperature setting. This study will have 9 temperature channels to measure 9 points in the room in accordance with the standard AS2853 in order to know the distribution of temperature in the room with detail, using a thermocouple type-k temperature sensor where the sensor can detect up to $200^{\circ} \mathrm{C}$ temperature, and this study equipped data storage on sd card with TXT file format so that users can easily access the data of temperature readings on $\mathrm{PC}$ (Personal Computer).

\section{MATERIALS AND METHODS}

\section{A. EXPERIMENTAL SETUP}

This study conducted a temperature recorder that provides 9 channels for measurement, using a k-type thermocouple temperature sensor. The use of an analog signal conditioning circuit and ATMegga 2560 to process the output from the sensor. After that, the temperature was displayed on the $4 \times 20$ character LCD. Temperature measurement data will be saved to the SD card every 10 seconds in the form of a TXT file. To test this research, it was necessary to use a sterilizer and a comparison tool in the form of a data logger, place the sensors at the measuring points of the sterilizer room according to the standard, then set the temperature on the sterilizer and start recording the temperature.

1) MATERIAL AND TOOL

This study uses a type-k thermocouple as a temperature sensor, then an analog signal conditioning circuit consisting of a filter, buffer, and non-inverting amplifier circuit. Using ATMega2560 as data processing, 4x20 character LCD as display, an SD Card, and RTC modules. The measuring instruments used in this research are an avometer and a data logger. The tools used in the experiment were a sterilizer with the Fortune ztp78e brand and Elektro-Mag M6040P. While the standard tool used as a comparison is the data logger Madgetech OctTemp2000.

\section{2) EXPERIMENT}

In this study, after the module is finished, an experiment will be carried out to record the temperature of the sterilizer for one hour, with temperature settings of $50 \mathrm{oC}, 100 \mathrm{oC}, 120 \mathrm{oC}$. Using standard tools as a comparison. All sensors will be placed at points according to the specified standard, in the study using the AS2853 standard reference. Each result of recording temperature setting data will calculate the error values and make a graph to compare and validate the results of this study.

\section{B. THE DIAGRAM BLOCK}

In FIGURE 1, When the ON / OFF switch on the tool is $\mathrm{ON}$, the entire circuit will get voltage from the battery. When the start button is pressed, the thermocouple temperature sensor that has been installed on the tool will detect the temperature and will be processed into the analog signal conditioning circuit. The output of the analog signal conditioning circuit is inputted to ATMega2560 for data processing and then displayed on a $4 \times 20$ LCD and the data is stored in the SD Card.

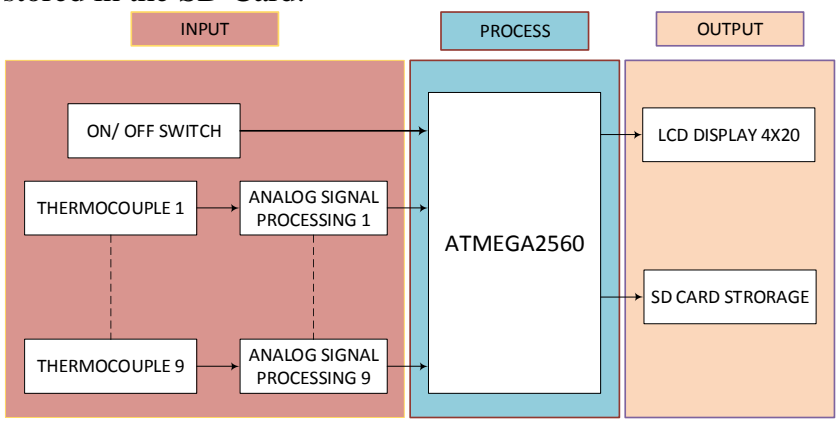

FIGURE 1. Diagram Block

\section{THE FLOWCHART}

In FIGURE 2 when the device is turned on, the initialization process will be carried out on the LCD and sensors. Then the thermocouple sensor will take temperature readings. The temperature reading results will be displayed on the device display and the temperature reading data will be stored in the SD Card. After the temperature reading data is saved, the user can insert the SD Card into the PC to open a txt file, then when 
the txt file is opened, a table of measurement results will be shown.
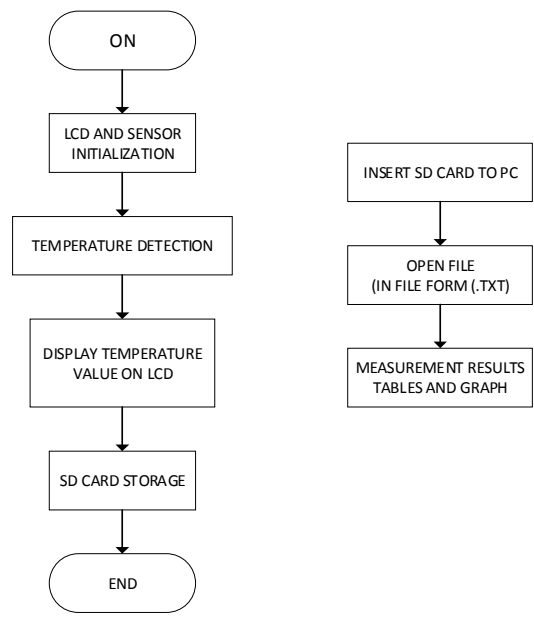

FIGURE 2. The Flowchart

\section{ANALOG CIRCUIT}

The most important part of this study is on FIGURE 3, that is analog signal conditioning circuit. Where there are a series of filters, buffers, and non-inverting amplifiers. The circuit serves to process the output of thermocouple sensors in the form of a small voltage of $0.004 \mathrm{mV}$ per increase of $1 \mathrm{oC}$, then will be changed from voltage to temperature using Arduino.

1) LOW PASS FILTER

The low pass filter circuit on FIGURE 4 serves to eliminate noise coming from the long sensor cable. The low pass filter circuit was designed with cut-off 3,387 and $1,592 \mathrm{~Hz}$ with the calculation:

$$
f=\frac{1}{2 \cdot \text { R.C }}
$$

\section{2) BUFFER}

The buffer circuit serves to support the received voltage so that when an output impedance of the circuit remains the same as the voltage received at the beginning.

$$
\text { Vout }=\text { Vin }
$$

\section{3) NON-INVERTING AMPLIFIER}

The non-inverting amplifier circuit is an amplifier with the characteristics of its output as effective as its input. In this study, an amplifier with a gain of 311 times was used.

$$
\text { Vout }=1+\mathrm{Rf} /(\mathrm{Ri})
$$

\section{RESULT}

The data logger was tested using a fortune ztp78e sterilisator and Elektro-Mag M6040P. The standard tool used for comparison is the Madgetech OctTemp2000 data logger.

\section{1) DESIGN MODULE}

As in FIGURE 3, this module used a type-k thermocouple as a temperature sensor, then an analog signal conditioning circuit consisting of a filter, buffer, and non-inverting amplifier circuit. Using ATMega2560 as data processing, $4 \times 20$ character LCD as display, an SD Card, and RTC modules. The measuring instruments used in this research are an avometer and a data logger.

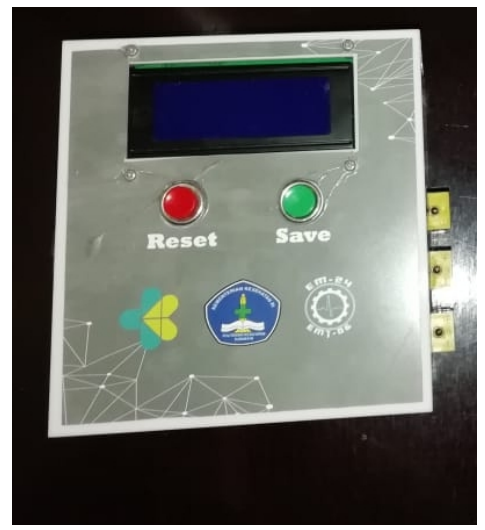

FIGURE 3. Module Design

\section{2) THE LISTING PROGRAM FOR ARDUINO}

The Arduino Mega microcontroller was used and the program was programmed through Arduino. The program on Arduino is shown in the program listing below.

Pseudocode: 1. ADC reading function using RMS formula

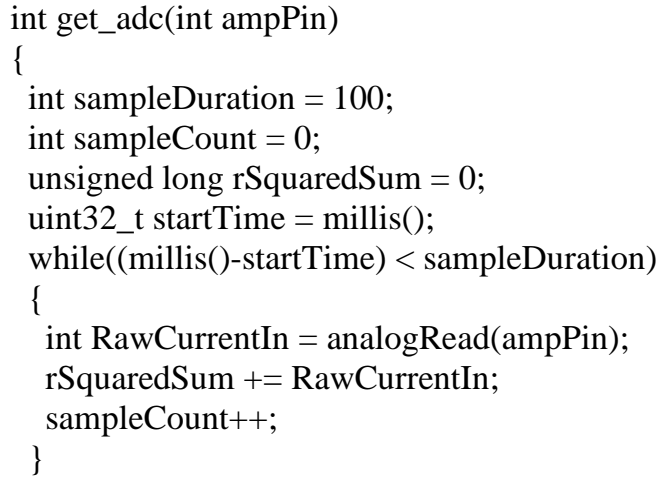

TABLE 1 shows the tesults of temperature measurements in design and standard

\begin{tabular}{|c|c|c|c|}
\hline \multicolumn{4}{|c|}{ Measurement results at $50^{\circ} \mathrm{C}$} \\
\hline Sensor & & UA & Error (\%) \\
\hline \multirow{2}{*}{$\mathrm{T} 1$} & $\mathrm{D}$ & 1,3 & \multirow{2}{*}{0,7} \\
\hline & $\mathrm{P}$ & 0,6 & \\
\hline \multirow{2}{*}{$\mathrm{T} 2$} & D & 0,7 & \multirow{2}{*}{3,9} \\
\hline & $\mathrm{P}$ & 0,3 & \\
\hline \multirow{2}{*}{ T3 } & $\mathrm{D}$ & 0,6 & \multirow{2}{*}{0,7} \\
\hline & $\mathrm{P}$ & 0,3 & \\
\hline \multirow{2}{*}{$\mathrm{T} 4$} & $\mathrm{D}$ & 0,7 & \multirow{2}{*}{3,3} \\
\hline & $\mathrm{P}$ & 0,6 & \\
\hline
\end{tabular}

TABLE 1

Measurement results at $50^{\circ} \mathrm{C}$ 


\begin{tabular}{cccc}
\hline \multirow{2}{*}{ T5 } & D & 0,3 & \multirow{2}{*}{2,0} \\
\cline { 2 - 3 } & P & 0,7 & \\
\multirow{2}{*}{ T6 } & D & 0,9 & \multirow{2}{*}{3,3} \\
\cline { 2 - 3 } & P & 0,3 \\
\multirow{2}{*}{ T7 } & D & 0,3 \\
\cline { 2 - 3 } & P & 0,0 \\
\multirow{2}{*}{ T8 } & D & 0,7 \\
\cline { 2 - 3 } & P & 0,3 & \multirow{2}{*}{1,3} \\
\hline \multirow{2}{*}{ T9 } & D & 0,7 & \multirow{2}{*}{1,4} \\
\hline
\end{tabular}

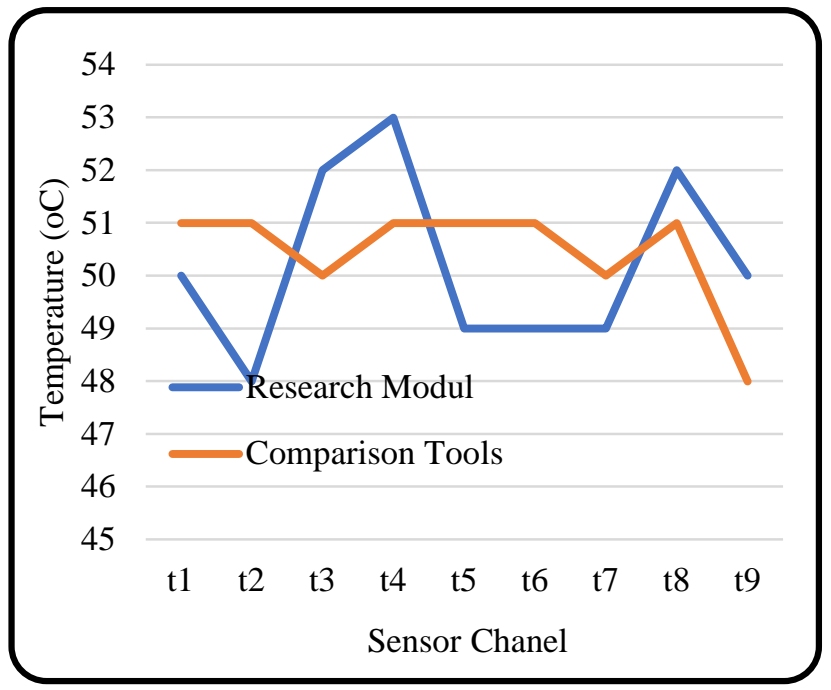

FIGURE 4. Graph of Temperature Measurement Results In Module And setting temperature $50^{\circ} \mathrm{C}$

Based on TABLE 1 and FIGURE 4 obtained the smallest average error value in the temperature data $50^{\circ} \mathrm{C}$ is $0.7 \%$ and the largest $3.9 \%$. Where $\mathbf{D}$ is a data logger (design), while $\mathbf{P}$ is a comparison device Madgetech OctTemp2000 (standard).

TABLE 2

\begin{tabular}{|c|c|c|c|}
\hline \multicolumn{4}{|c|}{ Measurement results at $100^{\circ} \mathrm{C}$} \\
\hline Sensor & & UA & Error (\%) \\
\hline \multirow{2}{*}{$\mathrm{T} 1$} & $\mathrm{D}$ & 0,3 & \multirow{2}{*}{4,7} \\
\hline & $\mathrm{P}$ & 0,3 & \\
\hline \multirow{2}{*}{$\mathrm{T} 2$} & $\mathrm{D}$ & 0,7 & \multirow{2}{*}{3,6} \\
\hline & $\mathrm{P}$ & 1,0 & \\
\hline \multirow{2}{*}{ T3 } & $\mathrm{D}$ & 0,3 & \multirow{2}{*}{5,1} \\
\hline & $\mathrm{P}$ & 0,3 & \\
\hline \multirow{2}{*}{$\mathrm{T} 4$} & $\mathrm{D}$ & 0,3 & \multirow{2}{*}{7,4} \\
\hline & $\mathrm{P}$ & 0,3 & \\
\hline \multirow{2}{*}{ T5 } & $\mathrm{D}$ & 0,3 & \multirow{2}{*}{5,8} \\
\hline & $\mathrm{P}$ & 0,3 & \\
\hline \multirow{2}{*}{ T6 } & $\mathrm{D}$ & 0,0 & \multirow{2}{*}{5,8} \\
\hline & $\mathrm{P}$ & 0,3 & \\
\hline \multirow{2}{*}{$\mathrm{T} 7$} & $\mathrm{D}$ & 0,3 & \multirow{2}{*}{10,5} \\
\hline & $\mathrm{P}$ & 0,3 & \\
\hline \multirow{2}{*}{$\mathrm{T} 8$} & $\mathrm{D}$ & 0,0 & \multirow{2}{*}{4,1} \\
\hline & $\mathrm{P}$ & 0,3 & \\
\hline T9 & $\mathrm{D}$ & 0,3 & 1,6 \\
\hline
\end{tabular}

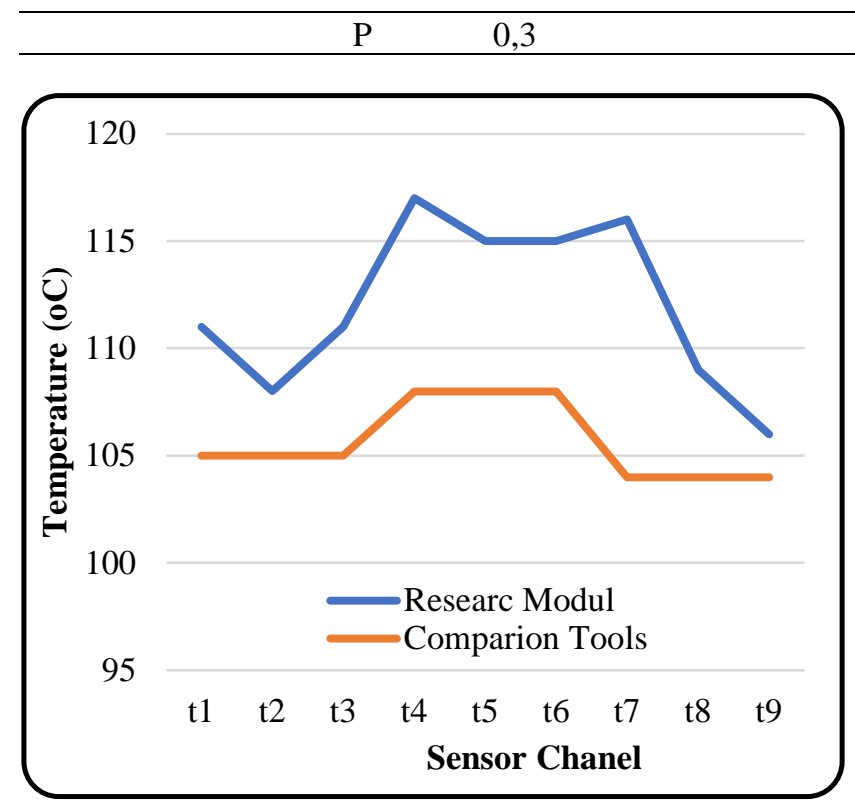

FIGURE 5. Graph of Temperature Measurement Results In Module And setting temperature $100^{\circ} \mathrm{C}$

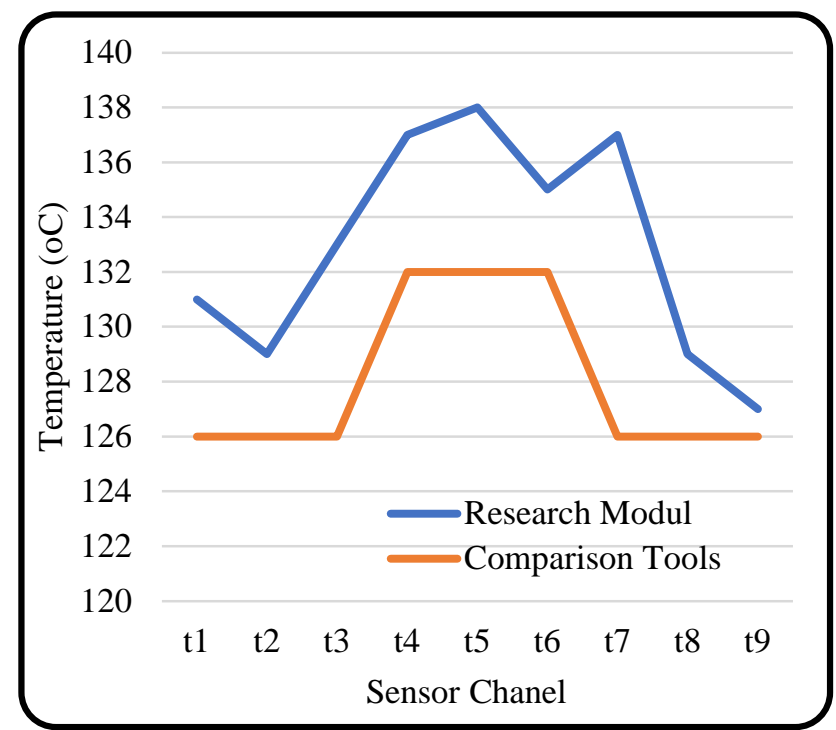

FIGURE 6. Graph of Temperature Measurement Results In Module And setting temperature $120^{\circ} \mathrm{C}$

Based on TABLE 2 and FIGURE 5 obtained the smallest average error value in the temperature data $100^{\circ} \mathrm{C}$ is $1.6 \%$ and the largest $10.5 \%$.

TABLE 3

\begin{tabular}{|c|c|c|c|}
\multicolumn{4}{c}{ Measurement results at $120^{\circ} \mathrm{C}$} \\
\hline \multirow{2}{*}{ Sensor } & & UA & Error (\%) \\
\hline \multirow{2}{*}{ T1 } & D & 0,3 & \multirow{2}{*}{4,0} \\
\cline { 2 - 3 } & P & 0,3 & \\
\hline \multirow{2}{*}{ T2 } & D & 0,3 & \multirow{2}{*}{3,2} \\
\cline { 2 - 3 } & P & 0,3 & 5,3 \\
\hline T3 & D & 0,3 & 5,3 \\
\hline
\end{tabular}




\begin{tabular}{|c|c|c|c|}
\hline & $\mathrm{P}$ & 0,0 & \multirow{3}{*}{4,1} \\
\hline \multirow{2}{*}{$\mathrm{T} 4$} & $\mathrm{D}$ & 0,3 & \\
\hline & $P$ & 0,6 & \\
\hline \multirow{2}{*}{ T5 } & $\mathrm{D}$ & 0,7 & \multirow{2}{*}{4,3} \\
\hline & $\mathrm{P}$ & 0,6 & \\
\hline \multirow{2}{*}{ T6 } & D & 0,3 & \multirow{2}{*}{2,3} \\
\hline & $\mathrm{P}$ & 0,3 & \\
\hline \multirow{2}{*}{$\mathrm{T} 7$} & $\mathrm{D}$ & 0,3 & \multirow{2}{*}{8,5} \\
\hline & $P$ & 0,3 & \\
\hline \multirow{2}{*}{$\mathrm{T} 8$} & D & 0,3 & \multirow{2}{*}{2,1} \\
\hline & $\mathrm{P}$ & 0,0 & \\
\hline \multirow{2}{*}{ T9 } & D & 0,3 & \multirow{2}{*}{0,0} \\
\hline & $\mathrm{P}$ & 0,3 & \\
\hline
\end{tabular}

Based on TABLE 3 and FIGURE 6 obtained the smallest average error value in the temperature data $120^{\circ} \mathrm{C}$ is $0.0 \%$ and the largest $8.5 \%$.

\section{DISCUSSION}

Temperature Data Logger research design conducted experiments to record the temperature on the sterilizer with a temperature setting of $50^{\circ} \mathrm{C}, 100^{\circ} \mathrm{C}, 120^{\circ} \mathrm{C}$. While the standard tool used as a comparison is madgetech OctTemp2000 data logger. All sensors was placed at points according to the specified standards, in the study using standard reference AS2853.

Based on measurement and comparison data, the average error was obtained at $50^{\circ} \mathrm{C}$ with the smallest error value of $0.7 \%$ and the largest value of $3.9 \%$. At $100^{\circ} \mathrm{C}$ the smallest error value is $1.6 \%$ and the largest is $10.5 \%$. Then at a temperature of $120^{\circ} \mathrm{C}$ is the smallest error value of $0.0 \%$ and the largest is $8.5 \%$. The result of the error in the measurement may be affected by the location of the sensor which may be very close to the heat source.

The calculation results obtained a fairly high error. However, this research can be improved on the analog signal conditioning circuit so that the error value is not too high. The implications of this research can help analyze the temperature distribution in a chamber of dry sterilizer..

\section{CONCLUSION}

The purpose of this study was to record and monitor whether the distributed temperature inside the dry sterilizers chamber matched the temperature setting. Based on measurement and comparison data, the average error was obtained at $50^{\circ} \mathrm{C}$ with the smallest error value of $0.7 \%$ and the largest value of $3.9 \%$. At $100^{\circ} \mathrm{C}$ the smallest error value is $1.6 \%$ and the largest is $10.5 \%$. Then at a temperature of $120^{\circ} \mathrm{C}$ is the smallest error value of $0.0 \%$ and the largest is $8.5 \%$. The development of this research can be done by Using another analog signal conditioning series so that the error value is not high and modules that are used on any device are not just measurements on dry sterilizers.

\section{REFERENCES}

[1] M. Virgo, Suwito, \& Tasripan, "Perancangan Data Logger Dengan Format CSV Menggunakan Mikrokontroler," Indones. J. Electron. Electromed. Eng. Med. informatics, vol. 1, no. 1, pp. 13-25, 2019, [Online]. Available: http://digilib.its.ac.id/public/ITS-paper-29822-
2206100019-Paper.pdf.

[2] D. Mussetyarsih, “" Data Logger Temperature Meter Pada Autoclave ," TEKNOKES, vol. 1, no. 1, p. 19750522, 2015.

[3] R. primaswara Bian, "Data Logger Temperature Meter pada Sterilisator Kering," TEKNOKES, vol. 1, no. 2015, p. 19750522, 2016.

[4] A. D. Korawan, "Rancang Bangun Data Logger Temperatur," SIMETRIS, vol. 12, no. 2, pp. 12-14, 2018.

[5] R. muhammad sadli, "Desain Data Logger Sensor Suhu Berbasis Mikrokontroler Atmega16," LITEK J. List. Telekomun. Elektron., vol. 17, no. 1, pp. 30-35, 2020.

[6] A. K. Bintari, A. Pudji, and Syaifudin, "Kalibrator Suhu Dengan Thermocouple Dan Thermohygrometer Dilengkapi Penyimpanan Data," TEKNOKES, vol. 1, no. 2013,pp. 0-5, 2016.

[7] J. Prinyakupt and T. Yootho, "Multichannel temperature monitor on IoT," BMEiCON 2016 - 9th Biomed. Eng. Int. Conf., vol. 1, no. 1, pp. $0-3,2017$.

[8] N. Kashyap and U. C. Pati, "Multi channel data acqusition and data logging system for meteorology application," 2015 Int. Conf. Smart Technol. Manag. Comput. Commun. Control. Energy Mater. ICSTM 2015 - Proc., vol. 1, no. May, pp. 220-225, 2015.

[9] O. Ojike, C. Mbajiorgu, E. Anoliefo, and W. Okonkwo, "Design and Analysis of a Multipoint Temperature Datalogger," Niger. J. Technol., vol. 35 , no. 2 , p. 458,2016

[10] A. Z. Febriyanti, P. C. Nugraha, and Syaifudin, "Temperature Calibrator Using Thermocouple Based on Microcontroller," IJEEMI, vol. 2, no. 1, pp. 13-20, 2020.

[11] R. Benyon, J. De Lucas, G. Elvira, and H. Fuentes, "The calibration of data loggers for the characterization of sterilization autoclaves," Int. J. Thermophys., vol. 32, no. 11-12, pp. 2504-2515, 2011.

[12] M. Abrar, "Pengembangan Model untuk Memprediksi Pengaruh Bakteri pada Susu Segar Development of Model to Predict Effect of Storage Temperature to Bacterial Growth Rate in Fresh Milk," $J$. Med. Vet., vol. 1, no. 2, pp. 109-112, 1999.

[13] F. R. Abadi and I. K. Tastra, "Kinerja DataLogger ' Datataker Dt80 'Menggunakan Dua Jenis Termokel Tipe K pada Pengukuran Sifat Termal Bahan Pertanian," IEEE, vol. 1, no. 1, pp. 706-716, 2017.

[14] S. Wardoyo, R. Munarto, and V. P. Putra, "Rancang Bangun Data Logger Suhu Menggunakan Labview," J. Ilm. Elit. ELEKTRO, vol. 4, no. 2013, pp. 23-30, 2013.

[15] D. Saepul Ramdan and M. Naufal Wijaksana, "Sistem Monitoring Suhu Cold Storage Menggunakan Data Logger Berbasis Arduino dan Visual Basic," KOPERTIP J. Ilm. Manaj. Inform. dan Komput., vol. 1, no. 3, pp. 107-112, 2017.

[16] M. Rofi'i and D. Titisari, "Calibration Waterbath 9 (CHANNEL)," Jeemi, vol. 1, no. 1, pp. 1-6, 2019.

[17] S. Wardoyo, A. P. Habibie, and R. Wiryadinata, "Wireless Data Logger Suhu Multi Channel Menggunakan Labview," J. Nas. Tek. Elektro dan Teknol. Inf., vol. 5, no. 2, pp. 10-15, 2016.

[18] N. V. Gupta and I. K. Purohit, "Temperature Mapping of Hot Air Oven (Dry Heat Sterilizer)," J. Pharm. Res., vol. 11, no. 2, pp. 18 20, 2017.

[19] S. N. Syayakti, E. D. Setioningsih, and S. Sumber, "4 Channel Sterilizer Calibrator," Indones. J. Electron. Electromed. Eng. Med. informatics, vol. 1, no. 2, pp. 65-70, 2020.

[20] Rizkiyatussani, Her Gumiwang Ariswati, and Syaifudin, "Five Channel Temperature Calibrator Using Thermocouple Sensors Equipped With Data Storage," J. Electron. Electromed. Eng. Med. Informatics, vol. 1, no. 1, pp. 1-5, 2019.

\section{ATTACHMENT}

Schematic and listing program https://drive.google.com/drive/folders/1kcg0jU 8Y8vhAOA-ZXUF911yuRyinihn?usp=sharing 